\title{
Geologic and Hydrologic Data Collected at Test Hole NC-8, Vega Alta, Puerto Rico
}

By Jesús Rodríguez-Martínez and Richard A. Scharlach

U.S. GEOLOGICAL SURVEY

Open-File Report 93-466

Prepared in cooperation with the

PUERTO RICO DEPARTMENT OF NATURAL RESOURCES 


\section{U.S. DEPARTMENT OF THE INTERIOR \\ BRUCE BABBITT, Secretary}

\section{U.S. GEOLOGICAL SURVEY}

Robert M. Hirsch, Acting Director

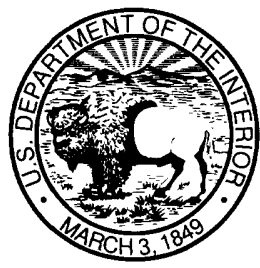

For additional information write to:

District Chief

U.S. Geological Survey

P.O. Box 364424

San Juan, Puerto Rico 00936-4424
Copies of this report can be purchased from:

U.S. Geological Survey

Earth Science Information Center

Open-File Reports Section, MS 517

Box 25286, Denver Federal Center

Denver, CO 80225 


\section{CONTENTS}

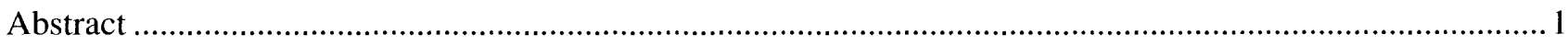

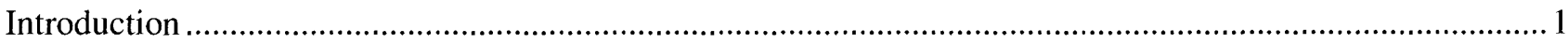

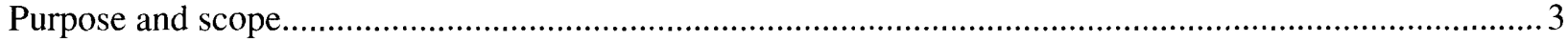

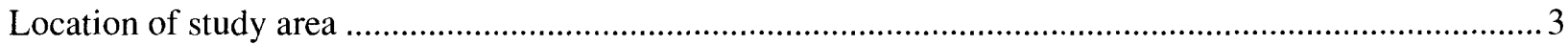

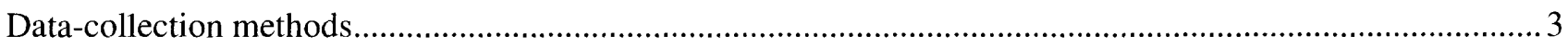

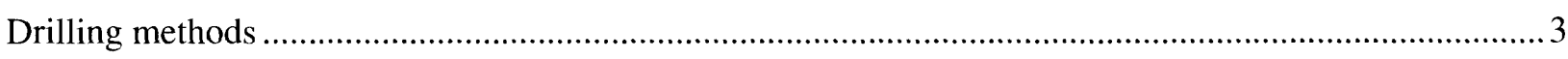

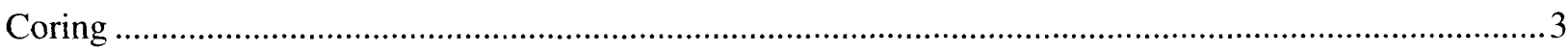

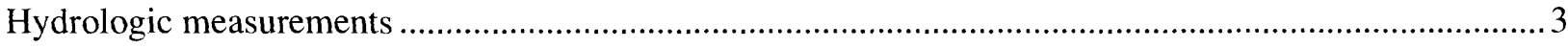

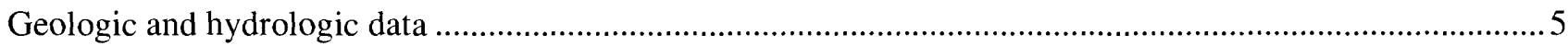

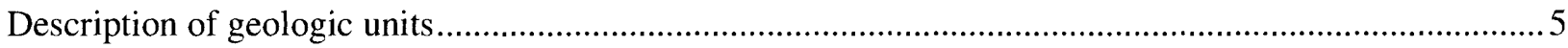

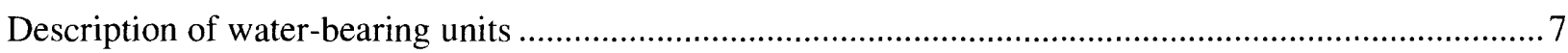

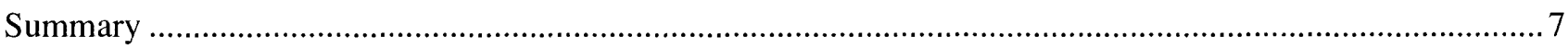

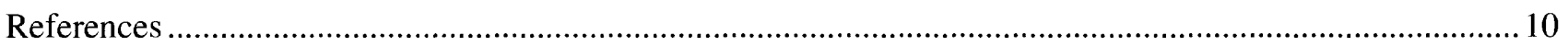

\section{FIGURES}

1. Map showing areal extent of the Northern Coastal Province of Puerto Rico

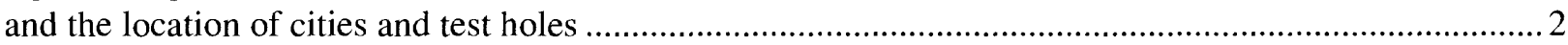

2. Map showing location of test hole NC-8 and surficial geology of the Vega

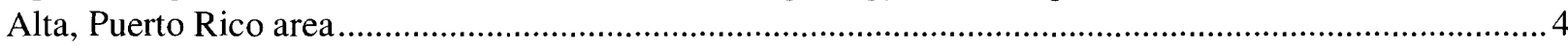

3. Chart showing the stratigraphic units comprising the middle Tertiary sequence of the Northern Coastal Province of Puerto Rico 6

4. Diagram showing geologic units, specific conductance, water level, and relative yield of test hole NC-8, Vega Alta, Puerto Rico 8

\section{TABLES}

1. Description of lithologic core of test hole NC-8, Vega Alta, Puerto Rico............................................. 11

2. Selected hydrologic data from test hole NC-8, Vega Alta, Puerto Rico.................................................. 9 
CONVERSION FACTORS AND ABBREVIATED WATER-QUALITY UNITS

\begin{tabular}{rll}
\hline Multiply & By & To obtain \\
\hline foot $(\mathrm{ft})$ & 0.3048 & meter \\
mile (mi) & 1.609 & kilometer \\
square mile (mi) & 2.590 & square kilometer \\
gallon per minute (gal/min) & 0.06308 & liter per second \\
\hline
\end{tabular}

Temperature in degrees Celsius $\left({ }^{\circ} \mathrm{C}\right)$ may be converted to degrees Fahrenheit $\left({ }^{\circ} \mathrm{F}\right)$ as follows: ${ }^{\circ} \mathrm{F}=1.8\left({ }^{\circ} \mathrm{C}\right)+32$

Abbreviated water-quality units used in this report:

microsiemens per centimeter at 25 degrees Celsius $(\mu \mathrm{S} / \mathrm{cm})$ 


\title{
Geologic and Hydrologic Data Collected at Test Hole NC-8, Vega Alta, Puerto Rico
}

\author{
By Jesús Rodríguez-Martínez ${ }^{1}$ and Richard A. Scharlach ${ }^{2}$
}

\section{Abstract}

Test hole NC-8 was drilled in the municipality of Vega Alta, as part of a study of the aquifers in the Northern Coastal Province of Puerto Rico. The total depth of the test hole was 1,736 feet below land surface. Hydrologic and geologic data collected during drilling included continuous lithologic core, waterquality data, water-level measurements, and estimates of relative yield from the water-bearing zones. Detailed petrological and microfaunal analyses of the core were made to determine the mineralogical content, ages, and paleoenvironments of deposition.

The core recovered from test hole $\mathrm{NC}-8$ indicated that the test hole penetrated five formations ranging in age from middle Oligocene to middle Miocene: the San Sebastián Formation, the Lares Limestone, the Cibao Formation, the Los Puertos Formation, and the Aymamón Limestone. Eight water-bearing units were encountered in NC-8: a water-table aquifer and seven artesian aquifers. The water-table aquifer contains the Los Puertos Formation and the uppermost stratas of the upper member of the Cibao Formation. The artesian aquifers occur in the Quebrada Arenas and Río Indio Limestone members of the Cibao Formation and the Lares Limestone. The water level varied from 79 to 83 feet below land surface in the water-table aquifer and from 11 to 59 feet below land surface in the artesian aquifers. No saltwater was encountered. The specific conductance of the water in the water-table aquifer ranged from 500 to 680 microsiemens per centimeter, while that of water in the artesian aquifers ranged and from 510 to 760 microsiemens per centimeter. The relative yield varied from 75 to 190 gallons per minute in the water-table aquifer and from 10 to 50 gallons per minute in the artesian aquifers. Subsequent to the acquisition of these data, test hole $\mathrm{NC}-8$ was plugged and abandoned.

\section{INTRODUCTION}

The Northern Coastal Province in Puerto Rico is part of a northward-thickening wedge of platform carbonates and minor clastics of Oligocene to Holocene age. This carbonate sequence underlies an area of approximately $700 \mathrm{mi}^{2}$ along the northern coast of the island from Aguada to Loíza (fig. 1). Extensive dissolution of limestone has created a humid tropical karst characterized by mogotes, sinks, and springs (Monroe, 1976).

Limited geologic and hydrologic data are available for the subsurface coastal region of northern Puerto Rico. As part of a cooperative study between the U.S. Geological Survey and the Puerto Rico Department of Natural Resources, 15 test holes were drilled (fig. 1) to determine the geologic and hydrologic characteristics of the aquifers and confining units of the Northern Coastal Province (Torres-González and Wolansky, 1984).

${ }^{1}$ U.S. Geological Survey, Water Resources Division, San Juan, Puerto Rico.

${ }^{2}$ Applied Earth Sciences, Inc., St. Rose, Louisiana. 


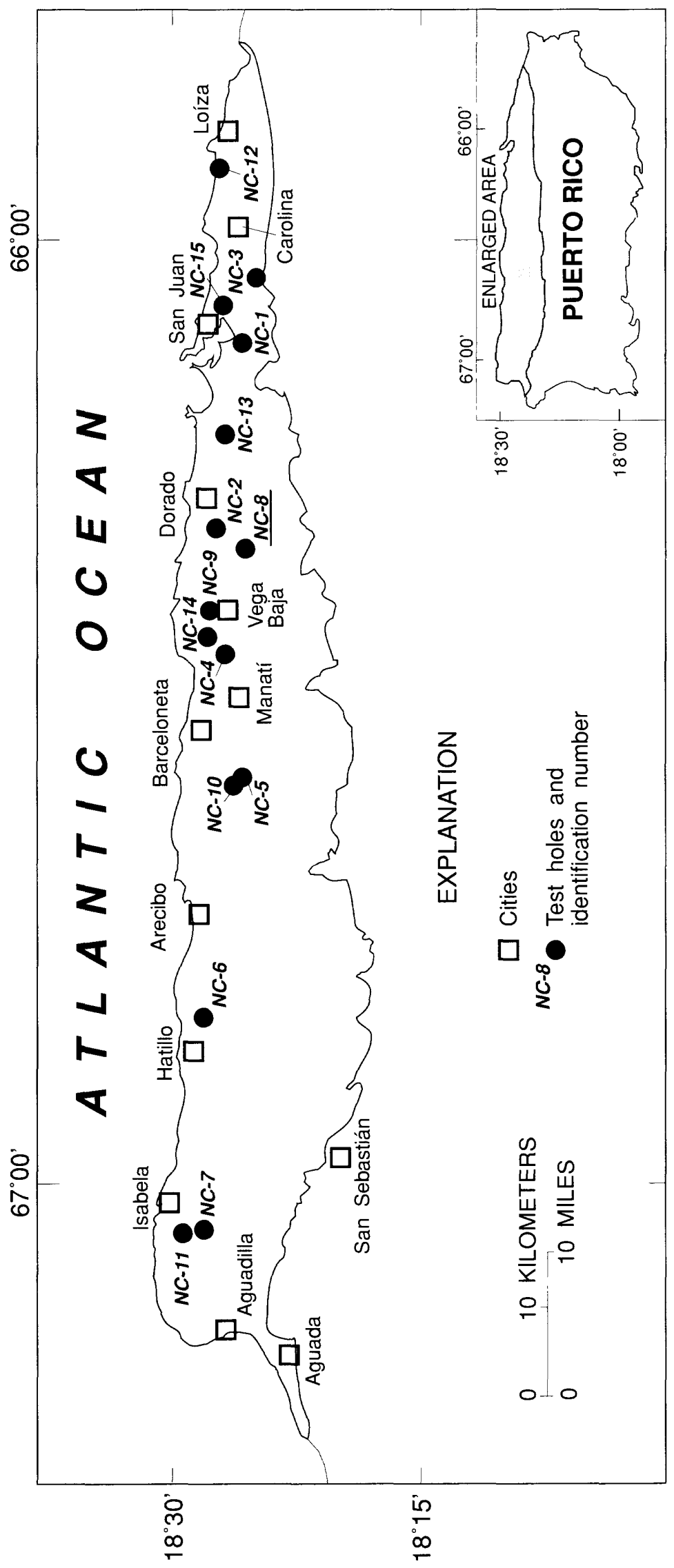




\section{Purpose and Scope}

This report presents the geologic and hydrologic data collected at test hole NC-8, drilled in 1986 in the municipality of Vega Alta, located in eastern north-central Puerto Rico. The data collected at the test hole include water levels, aquifer thickness, lithology, relative yield, and specific conductance of water from the major aquifers identified at this site. These data will assist in delineating major north coast hydrogeologic and geologic units and will help in quantifying the direction and rate of groundwater flow in the Northern Coastal Province.

The drilling and coring program was designed to allow the continuous collection of core samples for geologic, hydrogeologic, and paleontologic analyses. Water-level measurements were made and water-quality samples were collected from discrete water-bearing zones.

\section{Location of Study Area}

The municipality of Vega Alta is located in the eastern north-central part of Puerto Rico, approximately $15.6 \mathrm{mi}$ west of San Juan. The drilling site is located in the Espinosa sector of the municipality, about $0.31 \mathrm{mi}$ north of Highway 2 (fig. 2).

\section{DATA-COLLECTION METHODS}

A drilling method was used that allowed the continuous retrieval of lithologic core, as well as, the collection of water samples, head measurements, and water-flow estimates with minimum interruption of the drilling operations.

\section{Drilling Methods}

The test hole was drilled using a hydraulically driven, reverse air drill that uses pressurized air to remove cuttings from the borehole. The drill stem consisted of 20 -ft sections of threaded, seamless, double-walled pipe. As drilling progressed, air was forced under high pressure through the annulus between the two walls of the drill stem, forcing formation water and core samples up the center of the drill stem. Cores and water were ejected from the inner pipe into a large cyclone container that dissipate their energy and also served as a sample collector. Test hole NC-8 was plugged and abandoned after core collection and down-hole data acquisition were completed.

\section{Coring}

Test hole NC-8 was cored continuously from land surface to the total depth of the test hole. Core samples were retrieved, measured, described, and placed in wooden boxes for preservation and storage at the University of Puerto Rico at Mayaguiez. Each core box contains the equivalent of one drill stem length of core; approximately $20 \mathrm{ft}$. Representative core samples were selected for storage at the U.S. Geological Survey office in San Juan. Core recovery ranged from poor to excellent. Poor core recovery was common in cavernous zones.

\section{Hydrologic Measurements}

Water-level measurements were made at depth intervals of approximately $20 \mathrm{ft}$ using either an electric sensor or steel tape. Measurements were made on the inside of the drill pipe before the next section of drill stem was connected. Time restrictions prohibited a full recovery of water levels. Additional water-level measurements were made prior to the start of drilling activity each day and within selected intervals identified on the basis of a noticeable increase in water ejected from the discharge pipe.

Flow measurements were made at the discharge point of the cyclone collector. Although the measurements do not indicate the potential well yield of each of the waterbearing zones, they were made under approximately the same conditions, so that the measured flow reflects the relative yield of each zone. The flow data are therefore referred to as "relative yield." Hydraulic continuity and a sustained minimum flow of $10 \mathrm{gal} / \mathrm{min}$, measured at the discharge point of the cyclone collector, were used as criteria for differentiating water-bearing units. Specificconductance measurements were also made at the discharge point of the cyclone collector to examine the water quality of water-bearing zones. 

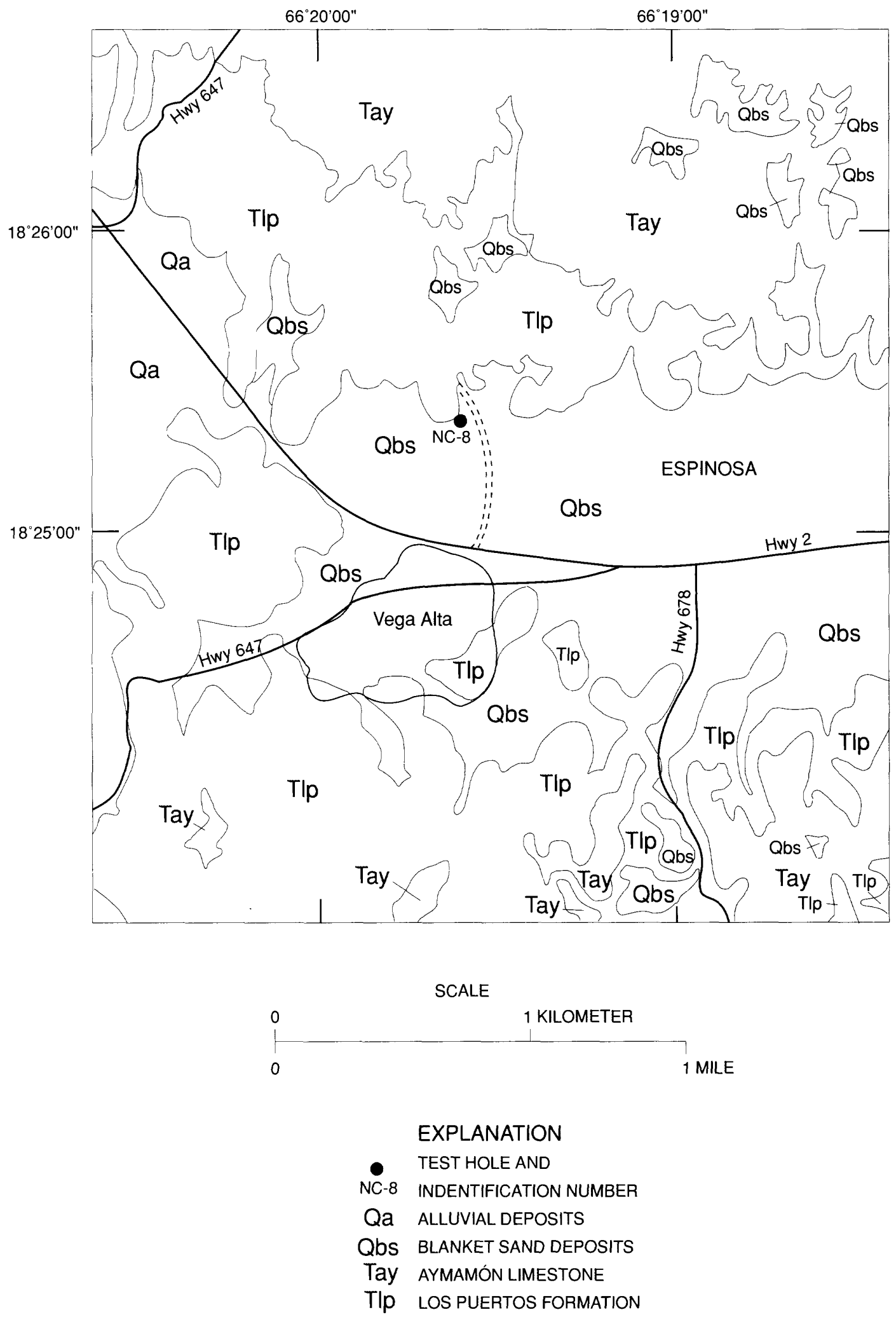

Figure 2. Location of test hole NC-8 and surficial geology of the Vega Alta, Puerto Rico area (Monroe, 1963). 


\section{GEOLOGIC AND HYDROLOGIC DATA}

In 1980, the rocks that crop out in the Northern Coastal Province were mapped as seven formations by Monroe (1980) on the basis of their lithologic character in the outcrop area. A few years later Seiglie and Moussa (1984) established a new geologic framework for these units using paleontologic data collected from cores, well cuttings, and outcrop samples (fig. 3). This report uses the nomenclature presented by Seiglie and Moussa (1984).

The municipality of Vega Alta is characterized by mogote and ridge karst topography. The surficial geology consists of the Aymamón Limestone, the Los Puertos Formation, and blanket sand deposits of Quaternary age (fig. 2). These lithologic units dip northward with an average slope of five degrees. This northward dip is interrupted by a structural terrace in the vicinity of the town of Vega Alta (Monroe, 1963).

The regional water-table aquifer has been the principal source of ground water in the Vega Alta area. However, it was not until 1960 that large scale development of the water-table aquifer began (Gómez-Gómez and TorresSierra, 1988). The hydrogeology of this regional waterbearing unit was described by Gómez-Gómez and TorresSierra (1988).

Prior to the drilling of test hole NC-8 in 1986, artesian conditions were suspected to exist in the Cibao Formation and in the Lares Limestone. These units are exposed along the southernmost border of the carbonate platform. No test hole or well in this region had penetrated deeper than the Aymamón Limestone and the Los Puertos Formation prior to 1986. Consequently, the local subsurface facies and hydraulic properties of the Cibao Formation, as well as, those of the Lares Limestone, were largely unknown.

\section{Description of Geologic Units}

In descending order, test hole NC-8 penetrated the Aymamón Limestone, the Los Puertos Formation, the Cibao Formation, the Lares Limestone, and the San Sebastián Formation (table 1, at end of report).

The Aymamón Limestone of middle Miocene age, is $74-\mathrm{ft}$ thick ( 0 to $74 \mathrm{ft}$ in depth) and is dominated by red algae packstone and grainstones. The Aymamón
Limestone is underlain by $206 \mathrm{ft}$ of the Los Puertos Formation (74 to $280 \mathrm{ft}$ in depth), composed of the following lithologic intervals: (a) $96 \mathrm{ft}$ (74 to $170 \mathrm{ft}$ in depth) of foraminifera, molluscan, coralline chalky wackestones and packstones; (b) $58 \mathrm{ft}$ (170 to $228 \mathrm{ft}$ in depth) of dolomitic marl and mudstone; and (c) $52 \mathrm{ft}$ (228 to $280 \mathrm{ft}$ in depth) of dolomitized molluscan (tables 1 and 2 ), foraminifera and red algae packstone with subordinate foraminifera-coralline wackestones and packstone.

The Cibao Formation, 525 - $\mathrm{ft}$ thick (280 to $805 \mathrm{ft}$ in depth), of Miocene and late Oligocene age underlies the Los Puertos Formation and is divided into the upper member and the undifferentiated Quebrada Arenas Limestone and the Río Indio Limestone Members. The 318 -ft thick upper member of the Cibao Formation (280 to $598 \mathrm{ft}$ in depth), consists of three units: (a) $170 \mathrm{ft}$ ( 280 to $450 \mathrm{ft}$ in depth) of foraminifera-sandy-clayey and locally dolomitic wackestone and packstone with minor claystone; (b) $60 \mathrm{ft}$ (450 to $510 \mathrm{ft}$ in depth) of mollusc and red algae packstone with lithic clasts; and (c) $88 \mathrm{ft}$ (510 to $598 \mathrm{ft}$ in depth) of red interbedded algae packstone, wackestones, and volcaniclastic conglomerates. The underlying undifferentiated Quebrada Arenas Limestone and the Río Indio Limestone Members are 207-ft thick (598 to $805 \mathrm{ft}$ in depth) and consist of a mixed carbonate and terrigenous lithology irregularly alternating between: Lepidocyclina grainstone litharenites, volcaniclastic conglomerates, claystone, and a skeletalcoralline-foraminifera wackestone-packstone and wackestone.

The 533-ft thick Lares Limestone (805 to 1,338 ft in depth) of Oligocene age underlies the Cibao Formation. The Lares Limestone consists of two lithologic units: (a) $305 \mathrm{ft}$ ( 805 to $1,110 \mathrm{ft}$ in depth) of echinoid-large benthic foraminifera, coral-bearing dolomitic wackestones, red algae and mollusc boundstone with minor, coralline-red algae boundstones and echinoid-large benthic foraminifera packstones; and (b) $228 \mathrm{ft}$ (1,110 to $1,338 \mathrm{ft}$ in depth) of skeletal-echinoid, red algae, large benthic foraminifera, locally clayey wackestones and packstones, with minor coralline packstones and grainstones.

Test hole NC-8 penetrated $398 \mathrm{ft}$ of the San Sebastián Formation (1,338 to $1,736 \mathrm{ft}$ in depth) underlying the Lares Limestone. The San Sebastián Formation is 


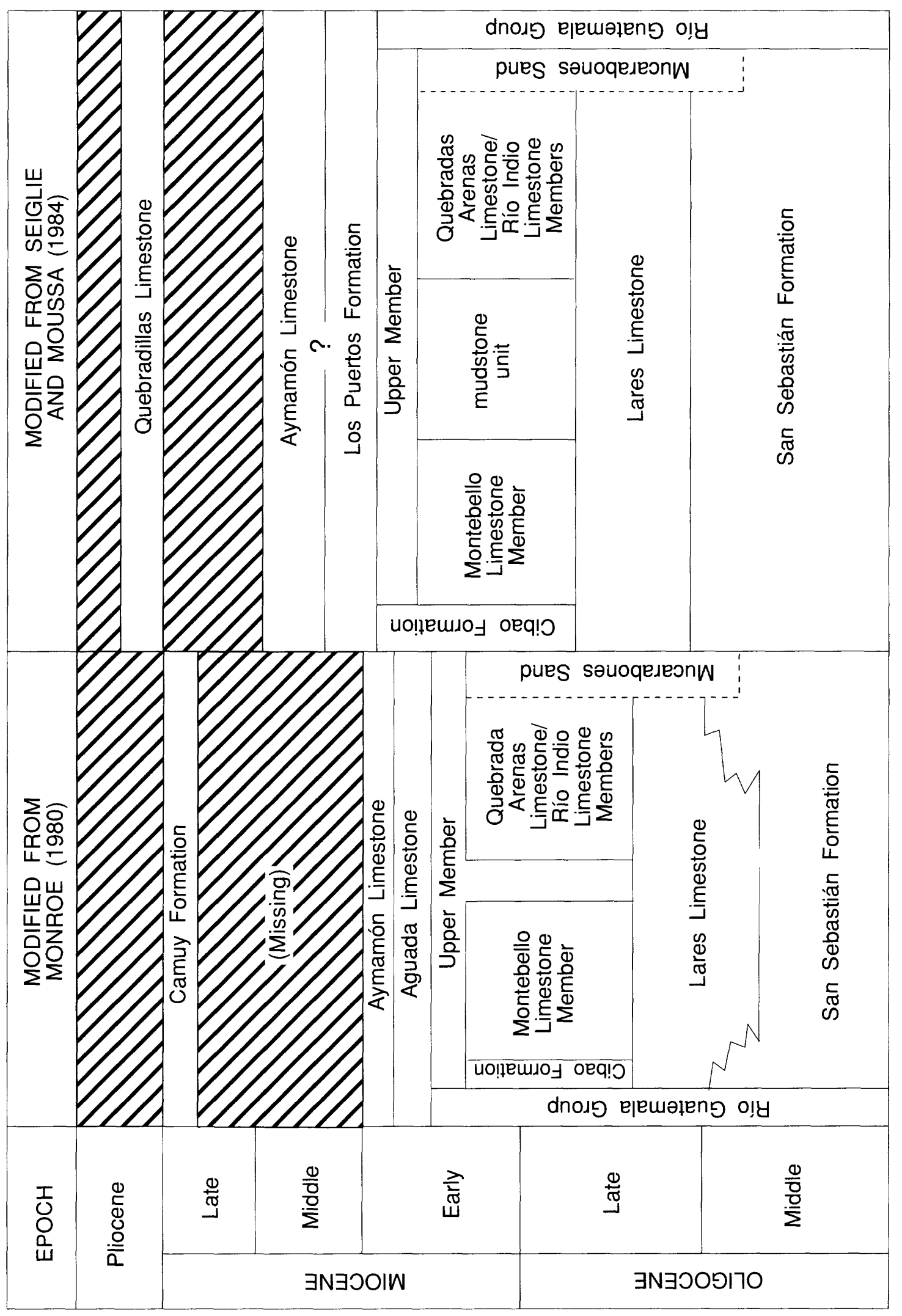

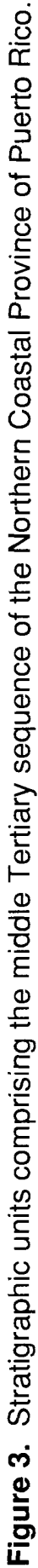


Oligocene in age and is composed of the following lithologic units: (a) $107 \mathrm{ft}$ (1,338 to 1,445 ft in depth) of foraminifera, red algae, echinoid packstone and wackestone, mollusc-ostracod wackestone and minor calcareous claystone (b) $15 \mathrm{ft}$ (1,445 to $1,460 \mathrm{ft}$ in depth) of interbedded clays and clayey quartz rich, articulate red algae, foraminifera-echinoid, clayey packstones (c) $60 \mathrm{ft}$ (1,460 to $1,520 \mathrm{ft}$ in depth) of dark-green clays, and clay rich oyster-pectinoid pelecypod, mollusc-bryozoan packstone; and (d) $216 \mathrm{ft}$ (1,520 to 1,736 ft in depth) of a variegated claystone becoming slightly calcareous near its top, containing sparse angular quartz, feldspar and volcanic rock fragments.

\section{Description of Water-Bearing Units}

Test hole NC-8 penetrated eight water-bearing units: a water-table aquifer and seven artesian aquifers (fig. 4). The uppermost water-bearing unit consists of the Los Puertos Formation and the uppermost stratas of the upper member of the Cibao Formation. This unit extends from the water table ( $79 \mathrm{ft}$ below land surface) to $358 \mathrm{ft}$ below land surface. A confining unit within the upper member of the Cibao Formation extends from 358 to $504 \mathrm{ft}$ below land surface. Underlying this confining unit is an artesian aquifer in the upper member of the Cibao Formation that extends to a depth of $520 \mathrm{ft}$ (16-ft thick).

A second confining unit contained in the lower part of the upper member and uppermost stratas of the Quebrada Arenas Limestone and Río Indio Limestone Members of the Cibao Formation extends to a depth of $601 \mathrm{ft}$. The underlying artesian aquifer located in the Quebrada Arenas Limestone and Río Indio Limestone Members extends from 601 to $653 \mathrm{ft}$. A 77-ft thick interval in the same undifferentiated unit contains three thin artesian aquifers (668 to $680 \mathrm{ft}, 693$ to $707 \mathrm{ft}$, and 714 to $731 \mathrm{ft}$ below land surface) and their corresponding confining units. This interval is underlain by a third confining unit also in the Quebrada Arenas Limestone and the Río Indio Limestone Members, extending from 731 to $742 \mathrm{ft}$. The underlying artesian aquifer, which is $36-\mathrm{ft}$ thick ( 744 to $780 \mathrm{ft}$ in depth), is contained within the lower part of the Quebrada Arenas Limestone and the Río Indio Limestone Members. The fourth, and lowermost confining unit in the Cibao Formation is 25 - $\mathrm{ft}$ thick (780 to $805 \mathrm{ft}$ in depth) and is contained in the lowermost strata of the Quebrada
Arenas Limestone and the Río Indio Limestone Members of the Cibao Formation. The underlying and basal artesian aquifer is 450 - $\mathrm{ft}$ thick ( 805 to $1,255 \mathrm{ft}$ in depth) and is contained within the Lares Limestone.

Specific-conductance measurements of water from $\mathrm{NC}-8$ varied from 500 to $680 \mu \mathrm{S} / \mathrm{cm}$ in the water-table aquifer and from 510 to $760 \mu \mathrm{S} / \mathrm{cm}$ in the artesian zones (fig. 4, table 2). Water levels within the aquifers varied from 79 to $83 \mathrm{ft}$ below land surface in the water-table aquifer, and from 11 to $59 \mathrm{ft}$ below land surface in the artesian aquifers (fig. 4, table 2). Estimates of relative yield during drilling ranged from 75 to $190 \mathrm{gal} / \mathrm{min}$ in the water-table aquifer and from 10 to $50 \mathrm{gal} / \mathrm{min}$ in the artesian aquifers (fig. 4 , table 2 ).

\section{SUMMARY}

This report presents data collected from test hole NC-8, drilled in 1986, in the municipality of Vega Alta, Puerto Rico. Test hole NC-8 was drilled to determine the depth, thickness, and hydraulic properties of the watertable aquifer and artesian aquifers of this area, as part of a study of the regional aquifer system in the Northern Coastal Province of Puerto Rico. Data collected from this test hole include core lithology, water levels, specific conductance of water, and relative yields.

Test hole NC-8 penetrated five formations ranging in age from middle Oligocene to middle Miocene. From deepest to shallowest, the formations penetrated were the San Sebastián Formation, the Lares Limestone, the Cibao Formation, the Los Puertos Formation, and the Aymamón Limestone.

Eight water-bearing units were penetrated by test hole NC-8: a water-table aquifer and seven artesian aquifers. Water levels varied from 79 to $83 \mathrm{ft}$ below land surface in the water-table aquifer, and from 11 to $59 \mathrm{ft}$ below land surface in the artesian aquifers. The relative yield ranged from 75 to $190 \mathrm{gal} / \mathrm{min}$ in the water-table aquifer and from 10 to $50 \mathrm{gal} / \mathrm{min}$ in the artesian aquifers. The specific conductance ranged from 500 to $680 \mu \mathrm{S} / \mathrm{cm}$ in the water-table aquifer and from 510 to $760 \mu \mathrm{S} / \mathrm{cm}$ in the artesian aquifers. Test hole NC-8 was plugged and abandoned, when data collection was completed. 
TEST HOLE NC-8

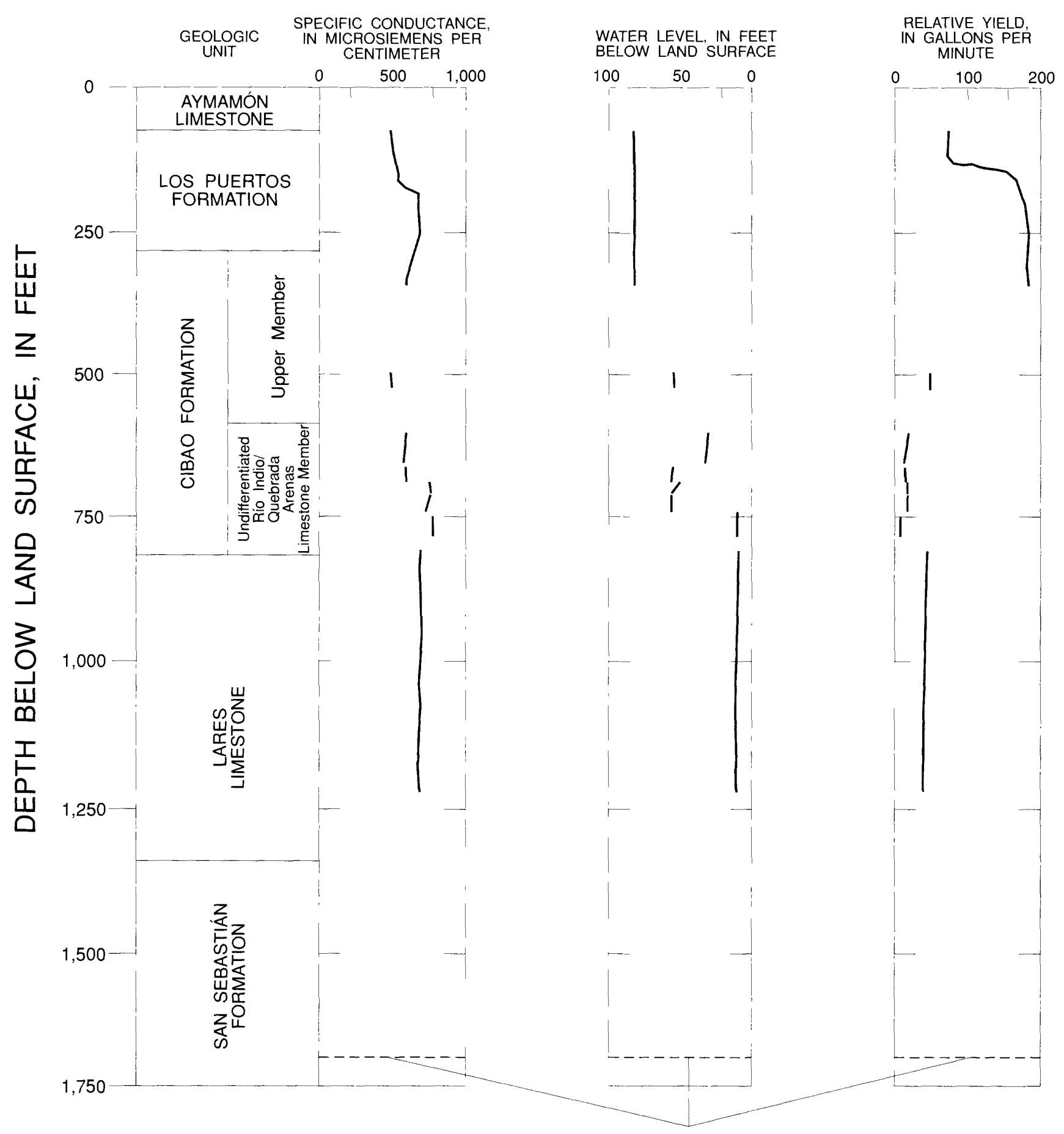

Total depth of test hole 1,736 feet

Figure 4. Geologic units, specific conductance, water levels, and relative yield at test hole NC-8, Vega Alta, Puerto Rico. 
Table 2. Selected hydrologic data from test hole NC-8, Vega Alta, Puerto Rico

\begin{tabular}{|c|c|c|c|}
\hline $\begin{array}{l}\text { Depth below } \\
\text { land surface } \\
\text { (feet) }\end{array}$ & $\begin{array}{l}\text { Water level } \\
\text { below land } \\
\text { surface (feet) }\end{array}$ & $\begin{array}{l}\text { Specific conductance } \\
\text { (microsiemens per } \\
\text { centimeter at 25) } \\
\text { degrees Celsius }\end{array}$ & $\begin{array}{l}\text { Yield } \\
\text { (gallons per } \\
\text { minute) }\end{array}$ \\
\hline \multicolumn{4}{|c|}{ Water-Table Aquifer } \\
\hline 79 & 79 & 500 & 75 \\
\hline 170 & 80 & 500 & 165 \\
\hline 200 & 80 & 650 & 180 \\
\hline 250 & 80 & 680 & 190 \\
\hline 300 & 82 & 625 & 190 \\
\hline 358 & 80 & 585 & 188 \\
\hline \multicolumn{4}{|c|}{ First Artesian Aquifer } \\
\hline 504 & 59 & 510 & 50 \\
\hline 505 & 59 & 510 & 50 \\
\hline 520 & 59 & 550 & 50 \\
\hline \multicolumn{4}{|c|}{ Second Artesian Aquifer } \\
\hline 601 & 34 & 560 & 20 \\
\hline 653 & 34 & 560 & 15 \\
\hline \multicolumn{4}{|c|}{ Third Artesian Aquifer } \\
\hline 668 & 59 & 580 & 15 \\
\hline 680 & 59 & 580 & 15 \\
\hline \multicolumn{4}{|c|}{ Fourth Artesian Aquifer } \\
\hline 693 & 52 & 750 & 10 \\
\hline 707 & 59 & 750 & 10 \\
\hline \multicolumn{4}{|c|}{ Fifth Artesian Aquifer } \\
\hline 714 & 59 & 750 & 15 \\
\hline 731 & 59 & 760 & 15 \\
\hline \multicolumn{4}{|c|}{ Sixth Artesian Aquifer } \\
\hline 742 & 11 & 760 & 12 \\
\hline 780 & 11 & 760 & 12 \\
\hline \multicolumn{4}{|c|}{ Seventh Artesian Aquifer } \\
\hline 805 & 11 & 700 & 45 \\
\hline 1,225 & 11 & 700 & 45 \\
\hline
\end{tabular}




\section{REFERENCES}

Goddard, E.N., and others, 1951, Rock-color chart: Washington, D.C., National Research Council, 6 p. (Republished by Geological Society of America, 1948; reprinted, 1963, 1970, 1975, 1979, 1980, 1984).

Gómez-Gómez, Fernando, and Torres-Sierra, Heriberto, 1988, Hydrology and effects of development on the water-table aquifer in the Vega Alta quadrangle, Puerto Rico: U.S. Geological Survey WaterResources Investigations Report 87-4105, 54 p.

Monroe, W.H., 1963, Geology of the Vega Alta quadrangle, Puerto Rico: U.S. Geological Survey Miscellaneous Geological Investigations Map GQ-191.

1976, The karst landforms of Puerto Rico: U.S. Geological Survey Professional Paper 899, 69 p., 1 pl.
1980, Geology of the middle Tertiary Formations of Puerto Rico: U.S. Geological Survey Professional Paper 953, 93 p.

Seiglie, G.A., and Moussa, M.T., 1984, Late OligocenePliocene transgressive-regressive cycles of sedimentation in northwestern Puerto Rico, in Schlee, J.S., ed., Interregional unconformities and hydrocarbon accumulation: American Association of Petroleum Geologists Memoir 36, p. 89-95.

Torres-González, Arturo, and Wolansky, R.M., 1984, Planning report for the comprehensive appraisal of the ground-water resources of the North Coast Limestone area of Puerto Rico: U.S. Geological Survey OpenFile Report 84-427, 32 p. 
Table 1. Description of lithologic core of test hole NC-8, Vega Alta, Puerto Rico

[(10YR8/4): Color code according to the Rock-Color Chart of the Geological Society of America, 1951]

Lithologic Description

Depth, in feet below

land surface

Miocene Series

Aymamón Limestone

Packstone, grayish-orange (10 YR 8/4); hard, crystalline; fossils

$0-30$

include red algae and foraminifera. Clay (soil), reddish-brown.

Grainstone, pale yellow-orange (10 YR 8/6), variably chalky to

$30-74$

hard, crystalline; fossils include peloids, articulate red algae, molluscs and echinoids. Porosity: present at 40 to 50 feet, but

filled or partly filled with reddish-brown clay or silt.

\section{Los Puertos Formation}

Packstone, pale yellowish-orange (10 YR 8/6), very pale orange

(10 YR 8/2), variable chalky and crystalline, hard; fossils include corals, molluscs, foraminifera, Kuphus; large vugs present at 110 to 115 feet filled or partially filled with reddish-brown clay/silt. Porosity: low-medium; moldic; and intraparticle.

Packstones-rudstones, grayish-orange (10 YR 7/4); fossils include $155-170$ branching corals, oysters, echinoids and a few small corals.

Porosity: low-medium; moldic.

Marl; mudstone, yellowish-gray, dolomitic, bioturbated; burrows $170-228$ with pyrite outlines. Porosity: low; interparticle; intercrystalline.

Packstone; lesser wackestone; yellowish-gray (5 Y 8/1), dolomitic;

fossils include molluscs, foraminifera (soritids, miliolids, and Amphistegina), and coralline red algae. Porosity: high-medium moldic, interparticle and intercrystalline (abundant molluscan and branching coral molds).

Wackestone; packstone, yellowish-gray (5 Y 8/1), light gray (N7), slightly sandy quartz; minor burrowing; some nearly pure dolomite layers; fossils include Halimeda, foraminifera (miliolids, soritids, peneroplids), and coral. Porosity: medium-high moldic, interparticle and intercrystalline.

\section{Cibao Formation}

\section{upper member}

Wackestone, greenish-gray (5 YR 6/1), quartz sandy; fossils include $280-311$ corals, molluscs, foraminifera (soritids and miliolids).

Porosity: medium-high; moldic; interparticle; intercrystalline. 

sandstones locally.

Wackestone, greenish-gray (5 GY 6/1), sandy quartz; fossils include $342-358$ foraminifera (soritids, miliolids), molluscs (including high-spired gastropods); variably dolomitic. Boundstone, same color; red algae most abundant fossil. Porosity: medium-high; moldic; interparticle; intercrystalline.

Claystone, olive, yellow-gray, yellow.

Wackestone, light greenish-gray (5 GY 8/1), quartz sandy; regularly interbedded with clays; fossils include soritids, miliolids, and gastropods.

Porosity: low.

Packstone, yellowish-gray (5 Y 8/1), dusky yellow (5 Y 6/4); often $450-510$ bearing lithoclasts; fossils include molluscs, foraminifera, red algae, branching coral fragments, cyclostome broyzoans, and Halimeda. Porosity: low-medium; moldic; intraparticle; interparticle.

Wackestone; packstone, clayey sandy quartz; fossils include fine $510-598$ articulate red algae and coalified plant remains (570-580 feet). Porosity: low; interparticle; moldic. Clays, olive, red, yellow, and purple. Conglomerates, yellowish-gray (5 Y 8/1), grayish-yellow (5 Y 8/4), poorly sorted; lithic and quartzose. Sands; well-rounded volcanic rock fragments at 510 to 515 feet, 527 to 531 feet, 535 to 540 feet, and 570 to 575 feet.

\section{Undifferentiated Quebrada Arenas and Río Indio}

\section{Limestone Members}

Grainstone, medium light gray(N6); locally grades to quartz-lithic echinoids and articulate red algae; a thin silty layer contain blackened organic plant remains and thin branching bryozoans. Porosity: low to medium depending on cementation; moldic; interparticle.

Clay, green-gray, calcareous.

Conglomeritic-rudstone, light gray (N7), yellowish-gray (5 Y 8/1), lithic; coral, red algae, and benthic foraminifera; crustose red algae coated volcanic rock and coral fragments in a micritic matrix containing large benthic foraminifera and oysters. Porosity: medium; moldic; interparticle; intraparticle. 
Grainstone, yellowish-gray (5 Y 8/1); fossils include molluscs, large

moldic.

Clays, greenish-gray.

Packstones; grainstones; yellowish-gray (5 Y 8/1); lower half of sequence is quartz and lithic; fossils include Lepidocyclina,

Heterostegina, Amphistegina and encrusting foraminifera,

Victoriella, Carpinteria, and molluscs; rhodolites common in the top 5 feet. Porosity: medium to high; interparticle; moldic.

Clays, yellowish-gray (5 Y 8/1), brown-black to dark-gray, silty;

thin layers of foraminifera limestones.

Wackestone-packstone, yellowish-gray (5 Y 8/1), slightly dolomitic;

fossils include large benthic foraminifera, red algae, echinoids and bryozoans; grades up to grainstone, lithic and sandy quartz.

Porosity: medium-high.

Rudstone, yellowish-gray (5 Y 8/1); fossils include corals, red algae, large benthic foraminifera, molluscs, echinoids, and bryozoans. Porosity: medium-high; interparticle; intraparticle; moldic; slightly reduced by coarse spar cement.

Sands; silts; clays; black to light gray (N6); sands are litharenites containing an estimated 60 percent volcanic rock fragments and quartz; skeletal grains include articulate red algae, molluscs (leached and later spar replaced) and echinoid parts; lesser components include ostracods, Halimeda, and phosphatic fish scales; grains rimmed with isopachus marine cement. Porosity: low moldic; blocky spar filled remaining pores.

\section{Oligocene Series}

\section{Lares Limestone}

Rudstone, yellowish-gray (5 Y 7/2), coralline; rhodolitic clasts in dolomitic clayey wackestone matrix; fossils in matrix include compact echinoid spines and molluscan fragments. Porosity: low (clay rich zones); medium; moldic; intercrystalline (dolomitic zones). 
Table 1. Description of lithologic core of test hole NC-8, Vega Alta, Puerto Rico--Continued

Lithologic Description

Depth, in feet below

land surface

Packstone, yellowish-gray (5 Y 8/1 and 5 Y 7/2), dolomitic, clayey;

$820-877$

fossils include corals, red algae, large benthic foraminifera and molluscs;

black larger skeletal grains give rock a speckled appearance.

Porosity: low-medium; intraparticle; moldic; interparticle. Dolomite,

same color as packstone; ranges from nearly pure to minor amounts

occurring as rhombehedrons along clayey seams (table 2).

Porosity: high-medium; moldic; intercrystalline.

Packstone-grainstone, yellowish-gray (5 Y 8/1 and 5 Y 7/2); sparsely

$877-905$

cemented; cross-bedded near bottom; fossils include red algae, molluscs,

large benthic foraminifera, and echinoids. Porosity: medium-high;

interparticle; intraparticle; moldic.

Wackestone, light olive-gray (5 Y 8/1), dolomitic; fossils include large

$905-915$

benthic foraminifera, red algae, and molluscs. Porosity: medium-high;

intercrystalline; interparticle.

Boundstone, yellowish-gray; geopetal structures common; coralline

and red algae, in a molluscan, echinoid, and articulate red algae

$915-935$

wackestone matrix. Porosity: medium; moldic; shelter.

Wackestone; packstone; grayish-yellow-green (5 GY 8/1 and

$935-985$

5 Y 7/2), fine sandy quartz, and plagioclase, dolomitic; vertical and

horizontal burrows; wavy laminations common; minor pyrite; fossils

include red algae, molluses, and large benthic foraminifera.

Porosity: medium-low; intercrystalline; interparticle; intraparticle.

Wackestone; packstone; grayish-yellow-green (5 GY 8/1 and

$985-1,015$

5 Y 7/2), matrix commonly neomorphosed micrite (microspar).

Porosity: low-medium; moldic; intraparticle; interparticle.

Wackestone; packstone; light olive-gray (5 Y 6/1), dolomitic, bioturbated, clay rich, slightly glauconitic; fossils include large benthic foraminifera, echinoid spines, articulate and crustose red algae, pelecypods, Lepidocyclina and Heterostegina, pectenoid pelecypods (in thin clay layers). Porosity: low-medium, locally high; intercrystalline; moldic.

Packstone, light olive-gray (5 Y 6/1), coarse grained; fossils include molluscs, large benthic foraminifera, echinoids and rare intraclasts. Porosity: low; intraparticle; moldic; shelter.

Wackestone; packstone, light olive-gray ( 5 Y 6/1), fine grained, $1,110-1,145$ dolomitic; minor clay; fossils include broken fragments of benthic foraminifera, echinoids, and pelecypods. Porosity: medium; intercrystalline; interparticle. 
Boundstone, light olive-gray (5 Y 6/1), yellowish-gray (5 Y 7/2), digitate rhodolites composed of red algae and encrusting foraminifera in large benthic foraminifera wackestone and packstone matrix; some non-rhodolitic layers; common bioclasts include Lepidociclyna, Miogypsina, and Heterostegina; less commonly miliolids and other smaller benthic foraminifera, pelecypods, echinoids and articulate red algae.

Porosity: medium-low; interparticle; moldic.

Wackestone-packstone, light olive-gray (5 Y 6/1); dolomitic micritic matrix; fossils include coralline, branching, and crustose red algae, large benthic and encrusting foraminifera. Porosity: medium; moldic; interparticle; intercrystalline.

Wackestone, light olive-gray (5 Y 6/1); some non-rhodolitic layers; $1,205-1,220$ common bioclasts include Lepidociclyna, Miogypsina, and Heterostegina; less commonly miliolid and other smaller benthic foraminifera, pelecypods, echinoids, and articulate red algae.

Packstone-grainstone, light olive-gray ( 5 Y 7/2), yellowish-gray (5 Y 6/10); fossils include branching red algae. large benthic foraminifera (Lepidocyclina and Heterostegina), echinoids and corals. Porosity: medium-low; moldic; interparticle; intraparticle; much original porosity by late calcite spar cementation.

Packstone-grainstone, light olive-gray ( 5 Y 7/2); same yellowish-gray ( 5 Y 6/10) but more clay rich. Wavy clayey partings common.

Porosity: low; interparticle; intraparticle.

Wackestone; packstone, light olive-gray (5 Y 6/1), greenish-gray ( 5 GY 6/1), clay rich, bioturbated; microstylolites; fossils include large benthic foraminifera, echinoids, corals, and pelecypods.

Porosity: low; interparticle; intraparticle.

\section{San Sebastián Formation}

Claystone, gray-green (5 GY 6/1), calcareous.

Packstone-grainstone, light olive-gray (5 Y 7/2); same yellowishgray $(5$ Y 6/10) with slightly higher clay content.

Packstones, greenish-gray (5 GY 6/1), clayey; thin clay-line wavy

laminations-microstylolites common; minor sparry calcite and pyrite cement; fossils include echinoids, molluscs, red algae, and foraminifera (Lepidocyclina, miliolids, and large encrusting foraminifera). Porosity: low; moldic; intraparticle; slightly reduced. 
Table 1. Description of lithologic core of test hole NC-8, Vega Alta, Puerto Rico--Continued

Lithologic Description

Depth, in feet below land surface

Limestone, coralline; clay-rich; molluscs, red algae-ostracode$1,386-1,445$ wackestone matrix; fossils include coral heads (recrystallized often with borings), oysters, and bryozoans; branching coral thicket at 1,397 feet. Porosity: low; interparticle.

Packstone, dark greenish-gray (5 GY 6/1); approximately 50 $1,445-1,460$ percent micrite matrix; clay and sandy quartz; glauconitic and phosphatic grains locally abundant; wavy clay laminations common; interbedded with claystone; fossils include articulate red algae, foraminifera, and echinoids. Porosity: low; moldic; interparticle; fine; slightly reduced by calcite and glauconite cements.

Packstone, dark greenish-gray (5 GY 6/1); sandy quartz, wavy $1,460-1,520$ clay-rich laminations; glauconite common in upper 20 feet; fossils include oysters, pectenoid pelecypods, echinoid plates, spines, and miliolids. Porosity: low; claystone, dark greenish-gray (5 GY 6/1), bearing branching red algae.

Claystones, grayish-olive-green (5 GY 4/2), red-brown, yellow-brown, $1,520-1,736$ purple calcareous; locally fine partings of black, organic matter with associated pyrite present; fossils include scattered thin-shelled pelecypod fragments, oysters, high-spired gastropods and ostracods. Porosity: low.

-U.S. GOVERNMENT PRINTING OFFICE: 1994-533-168/80015 